10IKC-221

\title{
EVIDENCE FROM INCLUSIONS IN DIAMONDS FOR 3 Ga ONSET OF THE SUPERCONTINENT CYCLE: IMPLICATIONS FOR GEODYNAMICS AND DIAMOND FORMATION
}

\section{Shirey* $\mathrm{SB}^{1}$ and Richardson $\mathrm{SH}^{2}$}

1. Department of Terrestrial Magnetism, Carnegie Institution of Washington, Washington D.C., USA

2. Department of Geological Science, University of Cape Town, Rondebosch 7701, South Africa

More than 20 kimberlites on 5 cratons have geochronologic studies on both their sulfide and silicate inclusion-bearing diamonds. This global dataset (Fig. 1) shows interesting systematic differences with age from the Archean to Proterozoic and can be used to test for secular changes in deep mantle processes and geodynamics. Geochronologic study of lithospheric diamonds uses the $\mathrm{Sm}-\mathrm{Nd}$ and $\mathrm{Rb}-\mathrm{Sr}$ systems on silicates of peridotitic

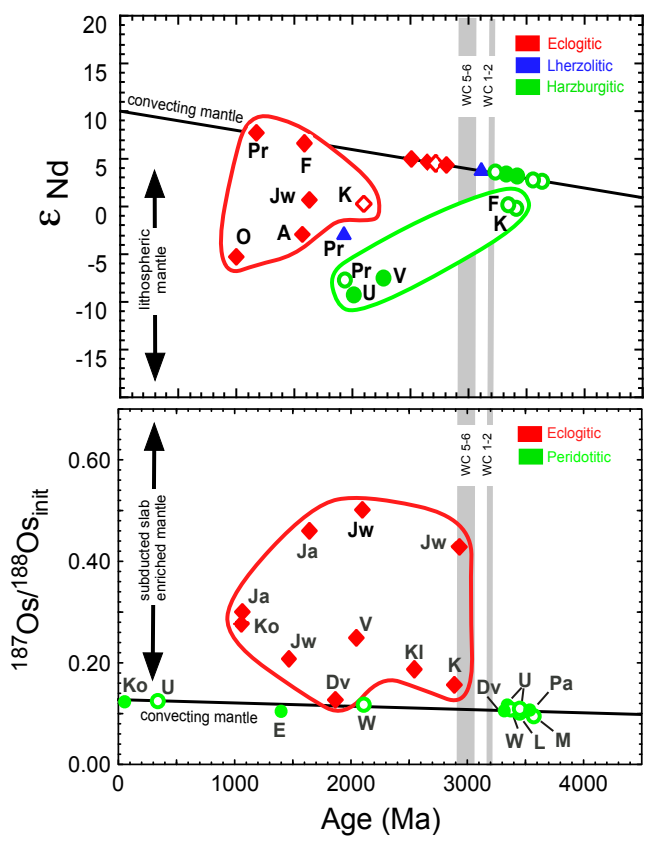

Fig. 1. (A) Silicate inclusion initial Nd iso- topic composition versus $\mathrm{Sm}-\mathrm{Nd}$ age for diamonds of peridotitic (circles), lherzolitic (triangles), and eclogitic (diamonds) parageneses. Solid symbols are isochron studies for composites of garnet and clinopyroxene grains; open symbols are model age studies for composites of garnet only. Unlabeled points on convecting mantle curve are mantle extraction ages extrapolated from labeled points (Shirey and Richardson, 2011). (B) Sulfide inclusion initial Os isotopic composition versus Re-Os age. Solid symbols are isochron studies; open symbols are model age studies for single grains. For isochron studies, mantle extraction ages extrapolated from labeled points are typically $<100$ million years (one scale division) older than the isochron age (11). In (A) and (B), WC 1-2 denotes Wilson cycle rifting (stages 1 and 2) for the Pilbara craton (6); WC 5-6 denotes Wilson cycle continental closure (stages 5 and 6) for the Kaapvaal craton. Locality abbreviations are given in Shirey and Richardson (2011) where this figure has been taken.

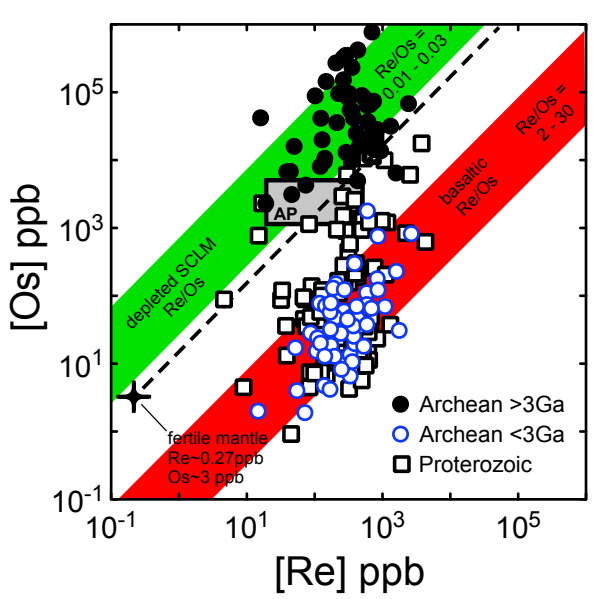

Fig. 2. Sulfide inclusions compared using measured Re and Os abundance in parts per billion (ppb) and grouped by age. Fertile mantle abundances from (Morgan, 1986) are for whole-rock peridotites. Field labeled AP encloses data for sulfides in present-day abyssal peridotites (Harvey, et al., 2006). Figure from Shirey and Richardson (2011).

(harzburgitic and lherzolitic) and eclogitic parageneses and the Re-Os system on sulfide inclusions of peridotitic (pentlendite-rich) and eclogitic (pyrrhotite-rich) parageneses. While sulfide and silicate inclusions rarely occur in the same diamond, they usually occur in the diamond population of each kimberlite.

Eclogitic silicate inclusion suites give $\mathrm{Sm}-\mathrm{Nd}$ isochron ages from 1 to $2 \mathrm{Ga}$, whereas peridotitic silicate inclusion suites give isochron or model ages from 1.9 to $3.4 \mathrm{Ga}$ (Fig. 1A). Most eclogitic and all peridotitic silicate inclusion suites form from protoliths enriched in light rare earth elements (LREEs; i.e., low ${ }^{147} \mathrm{Sm} /{ }^{144} \mathrm{Nd}$ ) that, at least for peridotitic silicate inclusions, require a two-stage history of depletion followed by strongly LREE-enriched alkalicarbonate metasomatism. Relative to eclogitic silicate inclusions, peridotitic silicates were encapsulated with systematically lower initial $\mathrm{Nd}$ isotopic compositions (Fig. 1A); moreover, the mantle extraction age for peridotitic silicate inclusions is much older than for eclogitic silicate inclusions. Most diamonds with eclogitic silicate inclusions formed later than $2.2 \mathrm{Ga}$, but their protoliths began to separate from the convecting mantle around $3.0 \mathrm{Ga}$, whereas peridotitic silicate inclusion protoliths date from 


\section{$10^{\text {th }}$ International Kimberlite Conference, Bangalore - 2012}

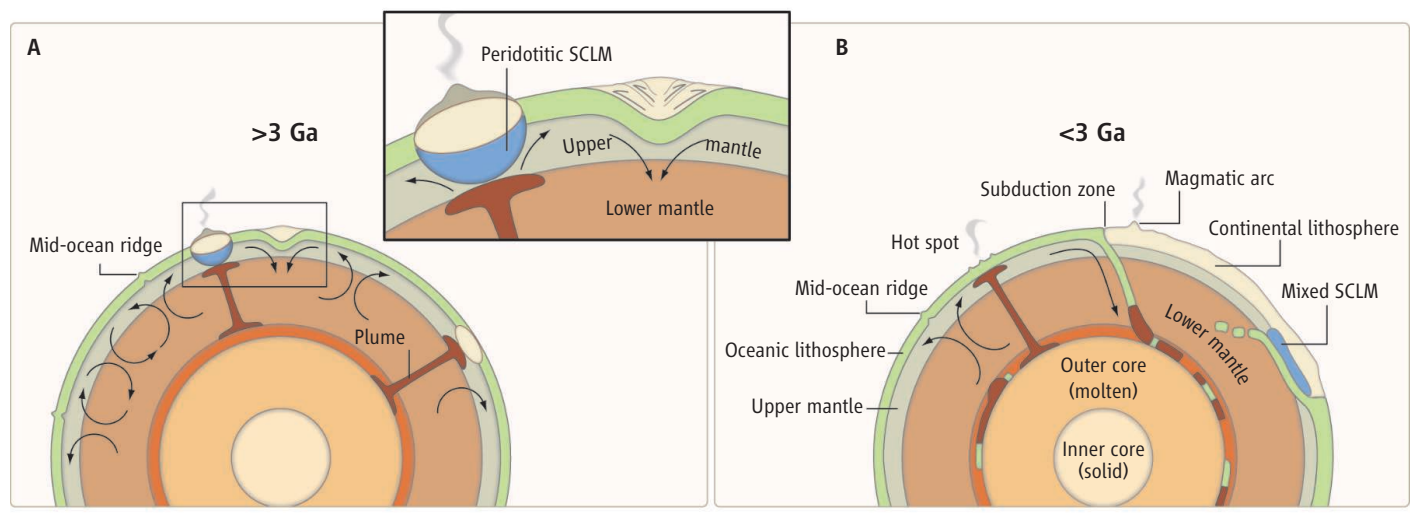

Figure 3. Schematic cross sections of (A) early Earth ( $>3 \mathrm{Ga}$ ) and (B) young Earth ( $<3 \mathrm{Ga})$, showing different modes of crust formation. On early Earth, crust formed in two settings (see enlargement): (i) over upwelling hot mantle, where it formed thick crust with a depleted keel of peridotitic subcontinental litho- spheric mantle (SCLM); (ii) over areas of downgoing mantle, where oceanic lithosphere was imbricated and extensively melted to form high-grade gneiss terrains. On young Earth with larger plates, whole- mantle convection generated steep subduction zones and the return of oceanic lithosphere to the mantle. Crust grew via subduction-generated arc magmatism and at hot spots. Subcretion of oceanic lithosphere to the base of continents resulted in SCLM with mixed peridotitic and eclogitic compositions. Figure and caption from Van Kranendonk (2011).

the Paleoarchean.

Single sulfide inclusions analyzed for Re-Os isochrons or model ages (Fig. 1B) show that the Archean and the Proterozoic were major eras of diamond formation. Although this is also the case for silicate inclusions, sulfide inclusions can be more specifically linked to geologic events, because there is a direct relationship between the $\mathrm{Re} / \mathrm{Os}$ ratio of the sulfide and that of the diamond protolith, given that sulfides crystallize from (or equilibrate directly with) diamond- forming C-O-H-S fluids. Eclogitic sulfides, with one exception, form from protoliths that have a systematically higher initial Os isotopic composition than do peridotitic sulfides. The isochron and mantle model ages for the peridotitic sulfides ex- tend to older ages than those of the eclogitic sulfides. Peridotitic sulfide inclusion protoliths typically date from the Paleoarchean; only rarely do peridotitic sulfides form at younger times. More important, the Paleoarchean was an era when diamonds with eclogitic sulfides did not form.

Diamonds $>3.2 \mathrm{Ga}$ contain exclusively peridotitic (harzburgitic) silicate and sulfide inclusions whereas diamonds $<3.0 \mathrm{Ga}$ contain predominantly eclogitic silicate and sulfide inclusions. Similarly, $>3.0$ Ga kimberlite-borne eclogite xenoliths are largely absent in the SCLM rock record, whereas they are common thereafter. This suggests that the depletion registered in the harzburgitic diamonds was associated with the igneous processes that created or at least followed closely on the creation of the first nascent stable cratonic lithosphere. Eclogitic silicate inclusions, with no exceptions so far, are Proterozoic and have ages that often match sulfide inclusions from the same kimberlite and the ages of tectonothermal events in overlying crustal rocks. This suggests that subduction-accretion was a major tectonic process operating on Earth since the Mesoarchean. These observations support the widespread invasion of already stabilized lithosphere by diamond forming fluids introduced by subduction at craton margins.

The composition of sulfide inclusions varies with age
(Fig. 2). Proterozoic and Archean ( $<3 \mathrm{Ga})$ sulfide inclusions show eclogitic or basaltic Re/Os ratios (2 to 30), with some Proterozoic inclusions trending toward lower $\mathrm{Re} / \mathrm{Os}$ ratios typical of the fertile mantle. Archean $(>3 \mathrm{Ga})$ sulfide inclusions show peridotitic Re/Os ratios (0.01 to 0.03 ) and plot in a group with higher Os contents and lower Re/Os ratios typical of depleted subcontinental mantle. Paleoarchean sulfides have low Re/Os because they crystallized in mantle peridotite that was residual after melt extraction that lowered its Re concentration to less than 10 parts per trillion. Sulfides younger than $3 \mathrm{Ga}$ have higher $\mathrm{Re} / \mathrm{Os}$ because they crystallized from basaltic or komatiitic (i.e., eclogitic) melting products of the mantle (Fig. 2).

We propose that this time is a boundary between different geodynamic regimes on Earth and the start of the supercontinent (Wilson) cycle. This temporal and geochemical change can perhaps best be explained as the result of a change in the tectonic style of the planet from rapid mantle convection, small plates, shallow subduction, and localized recycling $>3.2 \mathrm{Ga}$, followed by large plates, steep subduction, and full upper mantle recycling <3.0 Ga. These geodynamic changes would have had profound effects on how carbon bearing fluids are circulated and recycled in the mantle and consequently on mechanisms for diamond growth and current diamond distribution in the subcontinental lithospheric mantle.

Harvey J, Gannoun A, Burton K, Rogers N, Alard O, Parkinson I (2006) Ancient melt extraction from the oceanic upper mantle revealed by $\mathrm{Re}-\mathrm{Os}$ isotopes in abyssal peridotites from the MidAtlantic ridge. Earth and Planetary Science Letters 244(3-4): 606-621

Morgan J (1986) Ultramafic xenoliths: clues to Earth's late accretionary history. Journal of Geophysical Research 91:12,375-312,387

Shirey SB, Richardson SH (2011) Start of the Wilson Cycle at 3 Ga Shown by Diamonds from Subcontinental Mantle. Science 333:434-436

Van Kranendonk M (2011) Onset of Plate Tectonics. Science 333:413-414 